\title{
Earthy Practice
}

\section{Towards a History of Excavation in Sweden, in the $17^{\text {th }}$ and $18^{\text {th }}$ centuries}

\author{
Ola W. Jensen
}

\begin{abstract}
Excavation as a practice is commonly perceived as an outcome of the development of archaeology as a discipline during the $19^{\text {th }}$ century. In line with this argument, earlier antiquarians, such as Olof Rudbeck and Olof Verelius, were exceptions. In this paper, the author stresses that excavation as a method was established in the late $17^{\text {th }}$ century, only to become a natural practice in the next century. Issues that are ventilated are the circumstances behind this methodological introduction and its characteristics.

Ola W. Jensen, Department of Archaeology, University of Gothenburg, Box 200, SE-405 30, Göteborg, Sweden.
\end{abstract}

Key words: Archaeological practice, excavation, antiquarianism, history of archaeology.

The earth as a source and the spade as a tool are commonly perceived as the very emblems of archaeology. By archaeologists, the earth is chiefly appreciated for its ability to store and on a future occasion to give back some of its hidden valuables. No wonder then that the earth is often viewed as an archive storing information about the past. Or, to use another popular metaphor, as a book with pages (layers) waiting to be turned over and read by an educated translator, the archaeologist.

As the gate to the unknown, the earth has for a long time fascinated and stimulated man's imagination as to what it might be concealing. For some, it was the entrance to another dimension of life, the place for supernatural beings. For yet others, it was the place as where you could literally find the profit of your life; gold, silver and other valuables hidden but traceable, if you were eager enough to search for them. One feature often surveyed was ancient monuments. Many prehistoric graves were seen as potential hiding-places for treasure. This notion was attested by the fact that grave goods were frequently spotted by digging adventurers. However, the finds rarely consisted of precious metals but of urns, ashes and weapons; the real treasure were believed to have been withheld by their greedy owners, ghosts not seldom turned into dragons, evil personified. 
As time went by, the same monuments gained interest because of their age. In Sweden, interest in the past was established during the $15^{\text {th }}$ century. During the $16^{\text {th }}$ and the first half of the $17^{\text {th }}$ century, antiquarianism was gradually established, giving birth to a new occupational group, the antiquarians. Their mission included conducting inventories and studying different types of antiquities. However, their interest in the monuments was primarily focused on external features like shape, size and material. Knowledge of their inner constructions and the artefacts found within them were mainly the result of farming and treasure-hunting (Jensen 2002:333-334, Fig. 1). It was not until the second half of the $17^{\text {th }}$ century that their interiors and the earth, as such, were perceived as potential sources of information about past conditions. The situation was the same in the rest of Europe.

Why then were not the earth as a source and the spade as a tool viewed as natural components in the study of the past from the very beginning of the era of antiquarianism? Taking Sweden as an example, I shall in this article outline some of these factors, but also try to illustrate how, by whom, under what conditions and with what motives archaeological excavations were conducted during the $17^{\text {th }}$ and $18^{\text {th }}$ centuries.

\section{EARLY EXPLORATIONS OF THE EARTH AND THE MONUMENTS}

The oldest written testimonies of excavations concern the Orient and can be dated back some centuries BC. These enterprises were partly motivated by the search for treasure, but they also had a religious background and implied the search for artefacts related to a great ruler and/or a great period of history (Schnapp 1996:1379; Trigger 1989:29). This is comparable with the search for relics of Christianity

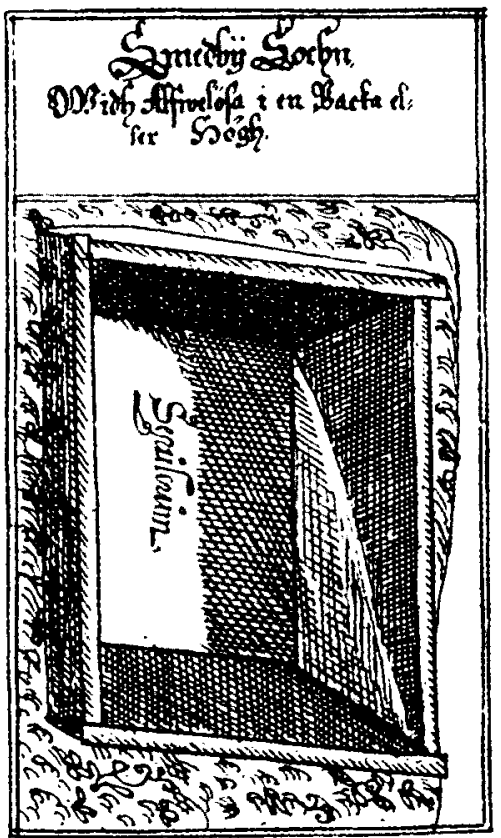
and some of the so-called högbrott in Scandinavia. Old Norse sources, early Nordic medieval laws and archaeological documentation indicate that ancient graves, most notably barrows, were quite frequently explored in all Scandinavia during the Viking Age and the early Middle Ages in the search for valuables and artefacts thought to have supernatural powers (Brendalsmo \& Røthe 1992; Jensen 2002:160161).

During the late Middle Ages, a new motive for exploring can be discerned on the continent. These investigations were mainly conducted by local monasteries and were dedicated to finding clues about past conditions, a motive for

Fig. l. Johannes Rhezelius'documentation from 1634 of a cist in a barrow in Smedby parish, Öland. It was explored by two "students" searching for treasure ( $F c 3 \mathrm{~b}$ ). 
excavating which became even more influential with the Renaissance. A famous example is the German Nicolaus Marschalk, who, as far as we know, was the first to perform an excavation in order to answer specific questions about different types of monuments, in his case megaliths and barrows (Schnapp 1996:142144).

A major problem in interpreting old sources about explorations in monuments is to discern why they were performed. As a rule, the only information presented is that someone penetrated a monument, finding this and that. The oldest examples concerning Sweden that I have found so far can be dated to 1559 , when two barrows were explored by different local men in Långhundra county, Uppland (UHRD 1942:116, 122). The motive was most probably to find treasure. In yet another case, the famous antiquarian Johannes Bureus noted an interpretation of a steenkrus (a stone jar) found in the late $16^{\text {th }}$ century in a so-called muurgrift (Fa 12, p 294). This term was sometimes used for cairns and stone-settings at the time. The jar contained a liquid which was thought to be beer and the grave in question was dated to the time of the Black Death, i. e. the Middle Ages. During that time, Bureus continued, people often dug their own graves, into which they introduced food and beer, in preparation for their coming deaths. Bureus' conclusion was that the habit of drinking beer in Sweden was indeed old!

\section{EXCAVATIONS DURING THE $17^{\mathrm{TH}}$ AND $18^{\mathrm{TH}}$ CENTURIES}

Whilst the early era of antiquarianism can be characterised as the period when monuments and other antiquities were surveyed, its second part, beginning in the mid- $17^{\text {th }}$ century, was the time when they truly became objects of knowledge. As such, they were explored, compared and analysed or, as the French historian of archacology Alain Schnapp put it, "the new antiquaries were encouraged to excavate, to construct chronologies, and to attempt reconstructions based on detailed observation of the earth and its monuments" (1996:198).

The famous natural historian Olof Rudbeck is often regarded as a predecessor of the scientific excavators (Klindt-Jensen 1975:30-31; Trotzig 1987:59; Wideen 1976:40-41). Rudbeck is known for his pioneering work of observing and measuring stratigraphical sequences. His aim was to date artefacts and the foundations of monuments, most notably barrows, with the ultimate objective of finding out when Sweden was first inhabited (Fig. 2; see also Eriksson 2002:292297). Even if he did not investigate thousands of barrows, which is the number he mentioned himself, he was undoubtedly one of the first to carry out excavations on a more regular basis, and also to analyse extensive, excavated material in order to interpret the past. As an example, he measured a great number of skeletons found in barrows in order to verify his hypothesis about prehistoric men being bigger the further north they lived (1937:400). Yet another analysis implied comparisons between different kinds of grave goods, in order to state the occupations of the dead (1937:86, 117, 410-411).

Rudbeck performed his excavations mainly in the Uppsala area during the 


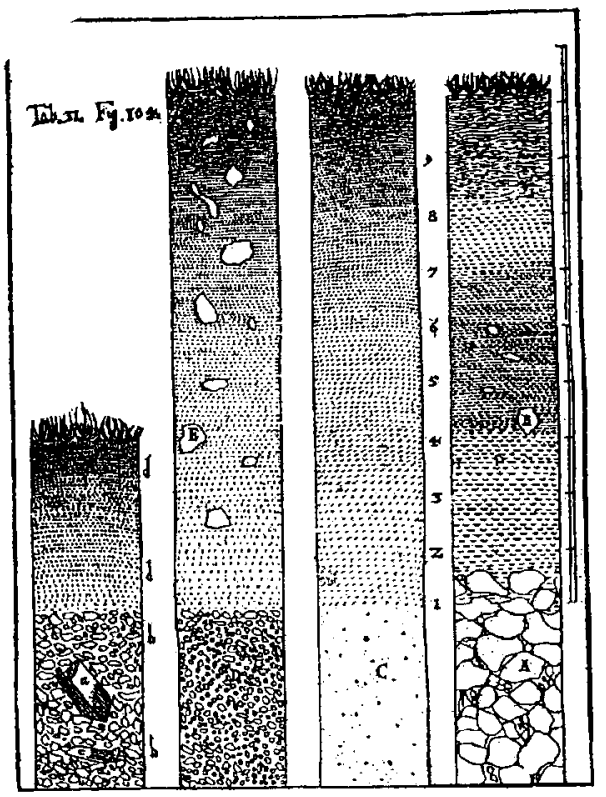

Fig. 2. Stratigraphical sequences and a measuring rod in Rudbeck's Atlanticans planschband (1679, unpaged). Rudbeck's theory was that since the Great Flood rotten vegetation and particles falling down in rain and snow had created a surface of mould. This svartmylla had also superimposed itself on ancient monuments, which, according to Rudbeck, could be dated by being measured (1937:81-92).

1670-80s. However, he was not the only one who fancied the art of excavation. Among the less famous examples is Per Brahe the Younger, who in 1655 excavated a barrow on the island of Visingsö in Lake Vänern. In 1669, Baron Per Ulfsparre examined Odens hög in Asa parish in Småland (Fig. 7), and in the 1680s the district judge Eric Teet explored a number of barrows in the county of Medelpad. At the end of the century, the antiquarian Johan Peringskiöld investigated a couple of barrows in Uppland, while Baron Jacob Gyllenborg investigated Björns hög, also called Hågahögen, in the same county (for further examples, see Jensen 2002:272-274). The first, well-documented excavation was performed by Olof Verelius, the antiquarian and the holder of the chair of Antiquarian Studies in Uppsala. In his translation of the Old Norse Götriks and Rolfs Saga, published in 1664, he gave a detailed account of his excavation of a barrow in Ullersåker, Uppland, carried out the year before (1664:80-83; for a translation into Swedish, see Jensen 1999:157-158). Like Rudbeck after him, Verelius also noted a stratigraphic sequence within the barrow.

It is commonly believed that the interest in antiquarianism suffered a severe decline during the $18^{\text {th }}$ century. This conclusion is mainly founded on the criticism that was raised against it at the time and the reduced interest regarding the centrally supported research conducted by the Archive of Antiquities, which was a reorganisation of the College of Antiquities founded in the mid-1660s. Consequently, it is also believed that the number of excavations carried out was indeed small. According to Bengt Hildebrand, this circumstance had a positive effect, since "the methods and the possibility of observing were still too undeveloped" (Hildebrand 1937:21-22; my translation). Contrary to earlier interpretations, my investigations indicate the existence of another side of the archaeological research. This would imply that the interest in antiquities was even greater than in the previous century. Local private research resulted in studies, inventories and excavations. An increasing interest can also be discerned within the university. Quite a few theses on the subject of antiquarianism were produced (Lindroth 1997a:628). 


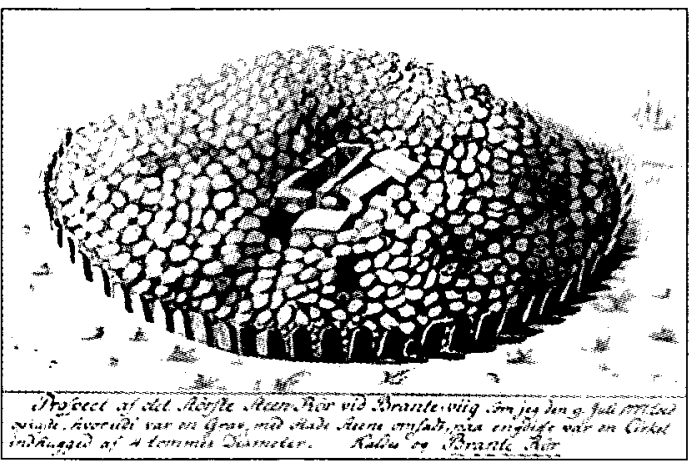

Fig. 3. A cairn called Brante rör situated in Jerrestad hundred, Kristianstad, which was investigated by C.G.G. Hilfeling in 1777 (Hilfeling 1977:96).

The continuous desire to perform archaeological research within the Archive of Antiquities is seldom noted. During their antiquarian journeys, Nils Wessman, Jacob Richardsson and Nils Reinhold Brocman carried out a number of excavations. It is worth noting that both Wessman, who investigated ten barrows in Skåne, and Brocman, who excavated six monuments of different types during his journey in northern Sweden, had their results presented in journals (Brocman 1766; Wessman 1758), whereas Jacob Richardsson presented his excavation of a barrow called Kungshögen near Halmstad in his work Hallandia antiqua et hodierna of 1752-53 (Fig. 9). Several other excavations were also presented in journals, magazines and books, which indicates an increasing public interest (cf. Fredenheim 1808; Ganander 1782; Hårleman 1753; Härnquist 1779a-b; von Schantz 1725; Sivers 1758 \& Åkerman 1774).

In 1786, the work of heritage preservation and the studies concerning antiquities that had previously been conducted by the Archive of Antiquities was taken over by the Royal Academy of Letters, History and Antiquities. No inventories or excavations were performed under their supervision (Schück 1943:310). The tradition of antiquarian journeys was, however, maintained by C.G.G. Hilfeling (see Nordbladh 1997). In the late 1760s and 1770s, Hilfeling lived in Copenhagen, Denmark, and was employed as an antiquarian draughtsman. From there, he made journeys to the old Danish territories of Skåne, Blekinge and Halland. In the 1780s, he moved back to Sweden. He became the private antiquarian of Baron Pehr Tham at Dagsnäs in Västergötland and made extensive documentations of antiquities in Gotland, Öland, Bohuslän and Västergötland. Like his precursors, Hilfeling also performed excavations (Figs. 3-4). On one occasion, in 1788, he and Tham performed an investigation or "anatomisering", as Tham put it, of a megalith situated in Stora Dala, Västergötland (Nordbladh 1997:531-532).

My investigations show that the number of excavations increased during $18^{\text {th }}$ century. Among the most famous examples are the Bronze Age cairn of Kiviksgraven in Skåne, found by treasure-hunters in 1748 and excavated by Wessman in 1756, and the well-documented excavation in 1724 of a barrow in Orkesta parish, Uppland (Fig. 5).

Even Carl von Linné (Linnaeus) excavated a number of monuments. In 1741, he examined what he called an atteplats in Öland, in order to find out if "ancient people were larger than they are at the present" (1977:86; my translation) and a hill fort situated on the same island for the purpose of analysing how it was 


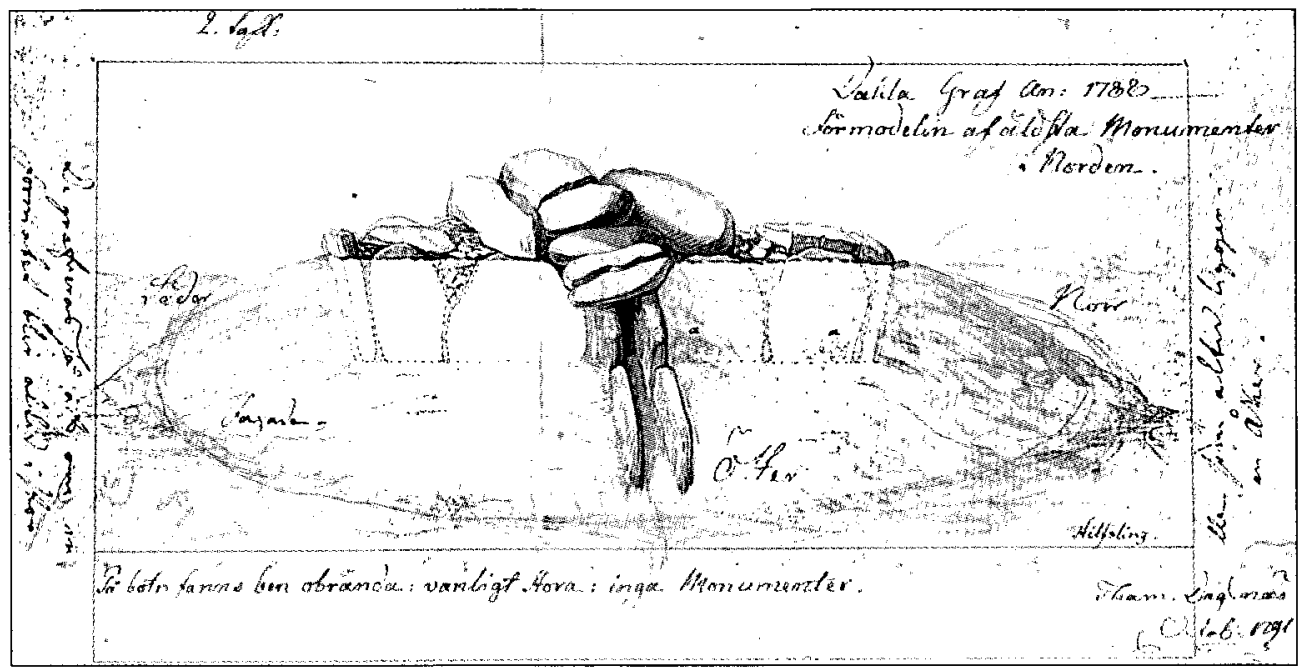

Fig. 4. A megalith in Stora Dala, Västergötland, documented by C.G.G. Hilfeling and excavated by him and Per Tham in 1788 (Persson \& Sjögren 2001:16).

constructed (ibid.101-102). It seems that he also excavated megaliths in Falbygden, Västergötland (1961:96). The "popularity" of excavations is perhaps best illustrated by the fact that the poet and historian Olof Dalin participated in an excavation and even wrote a poem about it (Fig. 6). Dalin is known for his severe criticism of antiquarianism, most notably the work performed by the so-called 'Rudbeckianerna'. Indeed, the fascination of exploring monuments even made people travel abroad. With permission from the Papacy itself, Carl Fredric Fredenheim in 1788-89 became the first to conduct an excavation in the Forum Romanum in Rome (Fredenheim 1808; see also Lindroth 1997b:220-224).

\section{CHARACTERISTICS OF THE EXCAVATIONS}

Excavation as a practice can be characterised as grave archaeology until the $20^{\text {th }}$ century. Barrows were the most excavated type of monument. Other forms of monument that were excavated during the $17^{\text {th }}$ and $18^{\text {th }}$ centuries, such as hillforts, cairns (besides Brocman and Hilfeling, see also Ganander 1782), megaliths

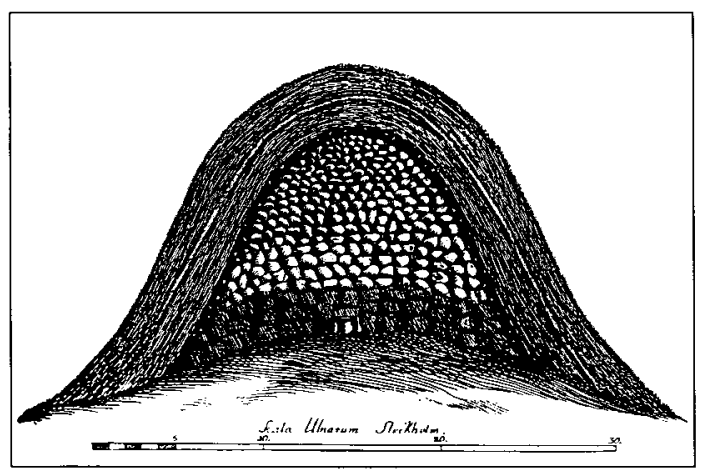
and medieval remains, such as monasteries (see Härnquist 1779a$b \&$ A kerman 1774), were exceptions. To some extent, attention was also paid to prehistoric settlements and cultural layers in medieval

Fig. 5. The profile of a barrow in Orkesta parish. Uppland, excavated in 1724 and documented by Carl Ludwig von Schantz (von Schantz 1725, unpaged; for the original drawing, see Schück 1935, unpaged). 


\begin{tabular}{|c|c|}
\hline & 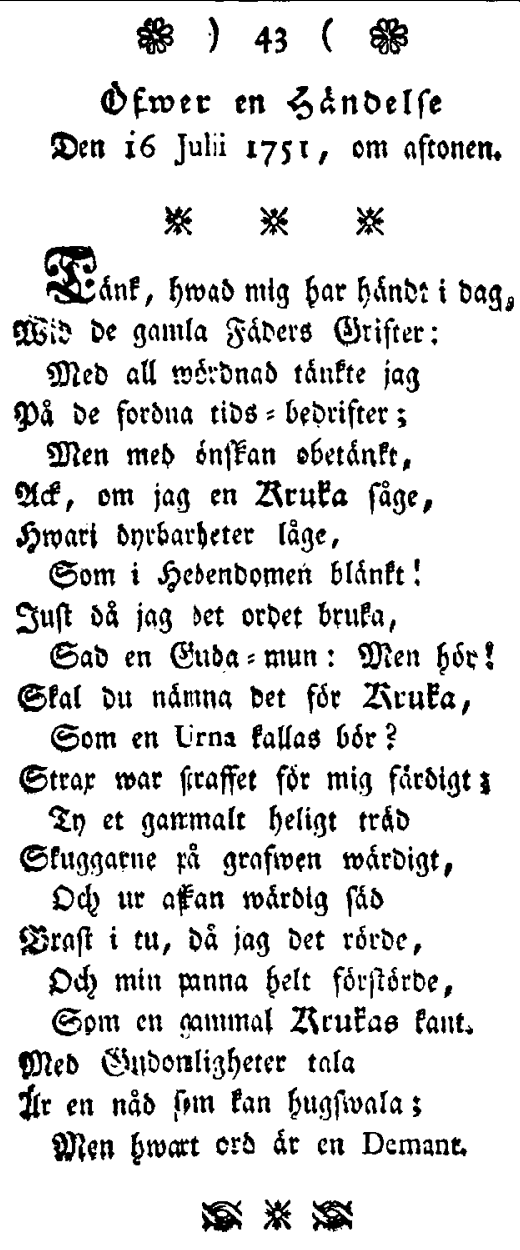 \\
\hline
\end{tabular}

Fig. 6. Dalin's poem about an excavation performed in 1751 (Dalin 1767:43). It was probably performed on the island of Lovön in Lake Mälaren, together with Queen Lovisa Ulrica and King Adolf Fredrik (see Arwidsson 1962:1/6).

cities. In the 1680s, the antiquarians Johan Hadorph and Johan Peringskiöld performed an excavation of the so-called "black earth" at the commercial, Viking Age town of Birka in Lake Mälaren (Hadorph 1687, unpaged).

Why this obsession with barrows? Next to rune-stones, barrows were by tradition paid most attention by antiquarians. Barrows were also hiding-places for grave goods, which was one important reason why they were excavated in the first place. Both the College of Antiquities and Olof Rudbeck had collections that contained artefacts found during excavations. In 1757, Henric Jacob Sivers excavated quite a few barrows in Tryserum parish near Kalmar, Småland (Sivers 1758; Fm 72). His comment on his newly acquired artefacts was that "they were a good contribution to my collection of antiquities" (1758:345-346, my translation). With some exceptions, like coins and rune-staves, smaller artefacts did not receive any serious attention until the second half of the $17^{\text {th }}$ century and the $18^{\text {th }}$ century (Jensen 2002:

283-287). This in turn coincided with an increasing interest in collecting curious things. Side by side with natural objects, such as fossils and minerals, both ethnographic and prehistoric artefacts were gathered in the popular cabinets of the time (Schnapp 1996:167-177). Thanks to the excavations performed, new types of artefacts were identified. The tradition of collecting curious things in cabinets was established as early as the $16^{\text {th }}$ century, and the purpose was didactic. The world and its natural and cultural components (macrocosmos) were represented and mirrored in the collections (microcosmos) (ibid.).

The average number of excavations performed by the individual was indeed small. One or two excavations were most common, preferably on one and the same occasion, which indicates a rather impulsive behaviour driven by a sudden curiosity (cf. Jonas Bruzelius in Stjerna 1906:7; Clas Julius Ekeblad Ie 14:2, p. 318; Severin Jacobsson Ström 1973:42-43 and Jonas Vollin 1933:86-87). The majority of the initiators were men. There were exceptions, though, such as Queen 
Lovisa Ulrika, who, together with King Adolf Fredrik, in the mid- $18^{\text {th }}$ century performed excavations on the island of Lovön in Lake Mälaren (Arwidsson 1962:116). Yet another example is Mrs Chamberlain Sara Maria Linroth, née Stedt. According to Erik Fernow, who was himself an experienced excavator at the time, she examined quite a few barrows in Ölme county, Värmland (Fernow 1977: 317, n. 220).

Another trait that the initiators had in common was that they were all members of the upper class or aristocracy and the learned part of society, such as antiquarians, barons, counts, governors, clergymen, etc. In many cases, the excavations were conducted on the initiator's own property. Apart from their scientific interest and the collecting of artefacts, private excavations were also performed as upperclass amusements. On one occasion, Sivers entertained his guests by excavating a couple of barrows (1758:343). The aim was to find urns, but their "only" discovery was a skeleton (ibid.344). The royal excavations performed at Lovön, on the other hand, were an appreciated court amusement during summer visits to the island (Arwidsson 1962:116). The royal interest in excavations is also demonstrated by the fact that King Karl XI in 1689 attended the excavation of a barrow in Gamla Uppsala, performed by Rudbeck (Rudbeck 1947:342).

Barrows were, with some exceptions (Fig. 10), seldom fully excavated because of their size. As could be expected, the men who actually performed the excavations were not the individuals who initiated the work, but local farmers and soldiers, i. e. two categories of workers experienced in digging, the former for their livings and the latter in constructing shelters for warfare. As civil servants and thereby representatives of the government, the antiquarians had the authority to require help from the locale people in conducting excavations. During his investigations in Hälsingland, Brocman requested help from the local people at a parish meeting ( $\mathrm{Fe} \mathrm{23,p} \mathrm{5).} \mathrm{Among} \mathrm{the} \mathrm{volunteers} \mathrm{was} \mathrm{an} \mathrm{old} \mathrm{farmer} \mathrm{who} \mathrm{in} \mathrm{his}$ earlier years had been a "hearty hill-digger", that is, a treasure-hunter (ibid. pp. 5-6). When investigating the barrow in Orkesta parish, the soldiers were ordered to perform the excavation by King Fredrik I himself (Schück 1935:232). The number of participants varied depending on the size of the barrow. During the investigation of the Orkesta barrow, no less than 40 soldiers from the Uppland Regiment participated (von Schantz 1725:34 and Schück 1935:233). Wessman, for his part, hired 30-40 peasants during the three weeks it took to excavate the 10 barrows in Skåne (Wessman 1758:13-15).

As regards the excavation technique and the methods used, there do not seem to have been any formalised practices. Indeed, apart from Rudbeck's comments on the dating of barrows, the first explicit discussions concerning methodological issues in Sweden can be dated back to the early $19^{\text {th }}$ century (cf. Schröder 1817). In order to measure the layers, Rudbeck constructed a measuring rod (Fig. 2). However, few attempts to date monuments by using this method seem to have been made after Rudbeck (for an example, see Rhyzelius 1707:25-26). As a matter of fact, the method was later criticised by Carl von Linné. During his 


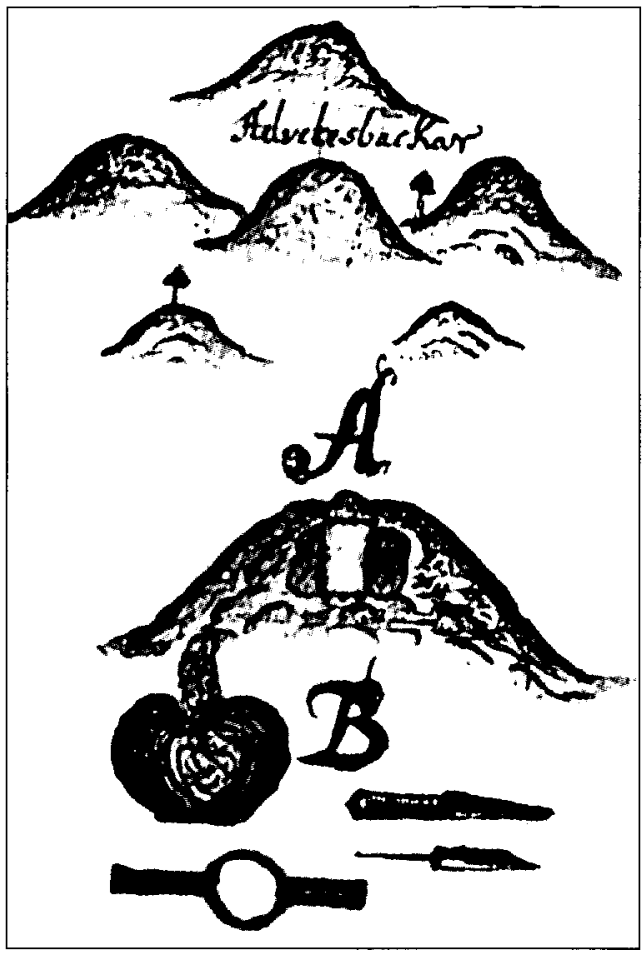

Fig. 7. Detail from a map made in 1693, illustrating the excavated Odens hög in Asa parish, Småland, and the artefacts found. It was investigated by Baron Per Ulfsparre in 1669 (Fm 53, pp. 34-35).

journey in Falbygden, Västergötland, von Linné noticed that the thickness of the earth covering the megaliths varied, depending on where they were situated and not, as Rudbeck thought, on their age. His argument was that the thickness of the earth was greater on monuments placed in meadows than on those in pastureland (1961:99). This criticism was perhaps fostered by the fact that huge cultural layers overlying old material remains were found in medieval cities. In his thesis on the early history of Lund from 1708, Andreas Stobaeus discussed different explanations for this. One of his conclusions was that Rudbeck's theory was insufficient to explain the town's large cultural layers (1708, chap. II, $\S$ I \& $\mathrm{VI})$.

The implements used were rough tools like spades, pickaxes and iron levers. Owing to the focus on the artefacts, the graves were perceived as containers, which meant that many excavations resembled treasure-hunting expeditions. And, as in the "smash and grab" method used by treasure-hunters, the excavators simply drove a hole to the centre of the grave in order to reach the goods (Figs. $3 \& 7$ ). As a consequence, construction details and smaller artefacts were often overlooked, and urns and other less durable artefacts were destroyed in the process.

In exceptional cases, when attention was paid to how the monuments were constructed, different strategies and more detailed documentation were required. As Rudbeck had done the century before (Figs. $2 \& 8$ ), shafts were dug both in the exploration of the Orkesta barrow and in that of the barrow excavated by Richardsson (Figs. $5 \&$ 9). The strategy used in the former case was to excavate the barrow from three different directions, from its sides and from its top. How then were they interpreted? During the whole of the period, barrows were chronologically ordered, depending on whether the body found was cremated or not. This idea was based on the information given in some Old Norse sources, most notably Snorre Sturluson's version of the Ynglingasaga (1994). According to this information, the custom of cremation was prior to the custom of burying the dead uncremated in barrows (the cremationage followed by the barrowage). The 


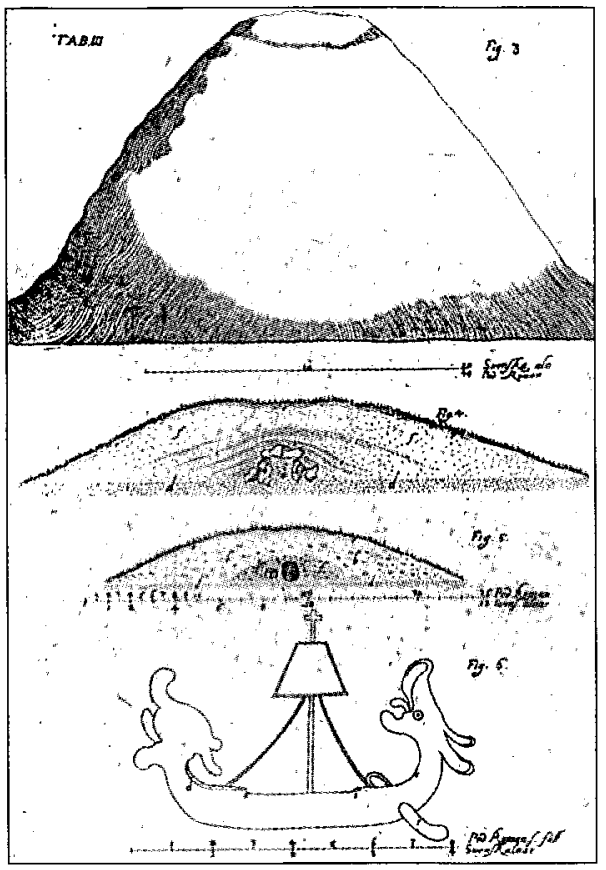

Fig. 8. Profiles of two barrows excavated by Olof Rudbeck (Atlanticans planschband 1679, unpaged).

sex of the dead, on the other hand, was determined by the gravegoods - weapons indicated a man's grave, while trinkets and jewels testified that it was a woman's (Jensen 2002:239-240; for examples, see Brocman 1766:553 and Sivers 1758:340).

The quality and amount of the documentation varied extensively during the period. In many cases, the excavation was mentioned only in a few lines. The fixation on artefacts implied that information about the monument itself was often overlooked. The quantity of illustrations increased during the period, especially concerning artefacts (Figs. 1112). To what extent the excavation was documented by drawings in the first place depended on who performed it - his interest and skill in drawing or his access to a professional illustrator. The staff of the Archive of Antiquities included illustrators. Carl Ludvig von Schantz, who documented the barrow in Orkesta, was one of them. Another one was Olof Rehn, who joined Brocman during his antiquarian journey to northern Sweden (Fig. 13). Hilfeling's skill with the pen is well illustrated in his drawings (Figs. 3-4), and Hårleman was a leading architect in Sweden at the time, which explains his detailed illustration of the excavated barrow in Fig. 10.

\section{TOWARDS AN UNDERSTANDING OF THE GROWTH OF EXCAVATIONS}

A common view is that excavation as a practice was established as an outcome of the development of archaeology during the $19^{\text {th }}$ century. Investigations made in the late $17^{\text {th }}$ century were, according to this argument, sporadic and a consequence of some individuals' work and the growing but transient interest in antiquarian issues. This in turn was due to the conflict with Denmark and the fact that both countries wanted to legitimise themselves with a grandiose past (Floderus \& Gustawsson 1946:264-267; Hildebrand 1937:21-22; Trigger 1989:48-49). The view outlined above shows that the practice of excavating was introduced during the second half of the $17^{\text {th }}$ century, only to be established as a more or less evident, archaeological method during the next century. The question to which I shall devote the last sections is why and under what circumstances this was the case.

Looking at the work of individuals, I believe that they were important as regarded the way in which excavation was performed and modified. Each ex- 


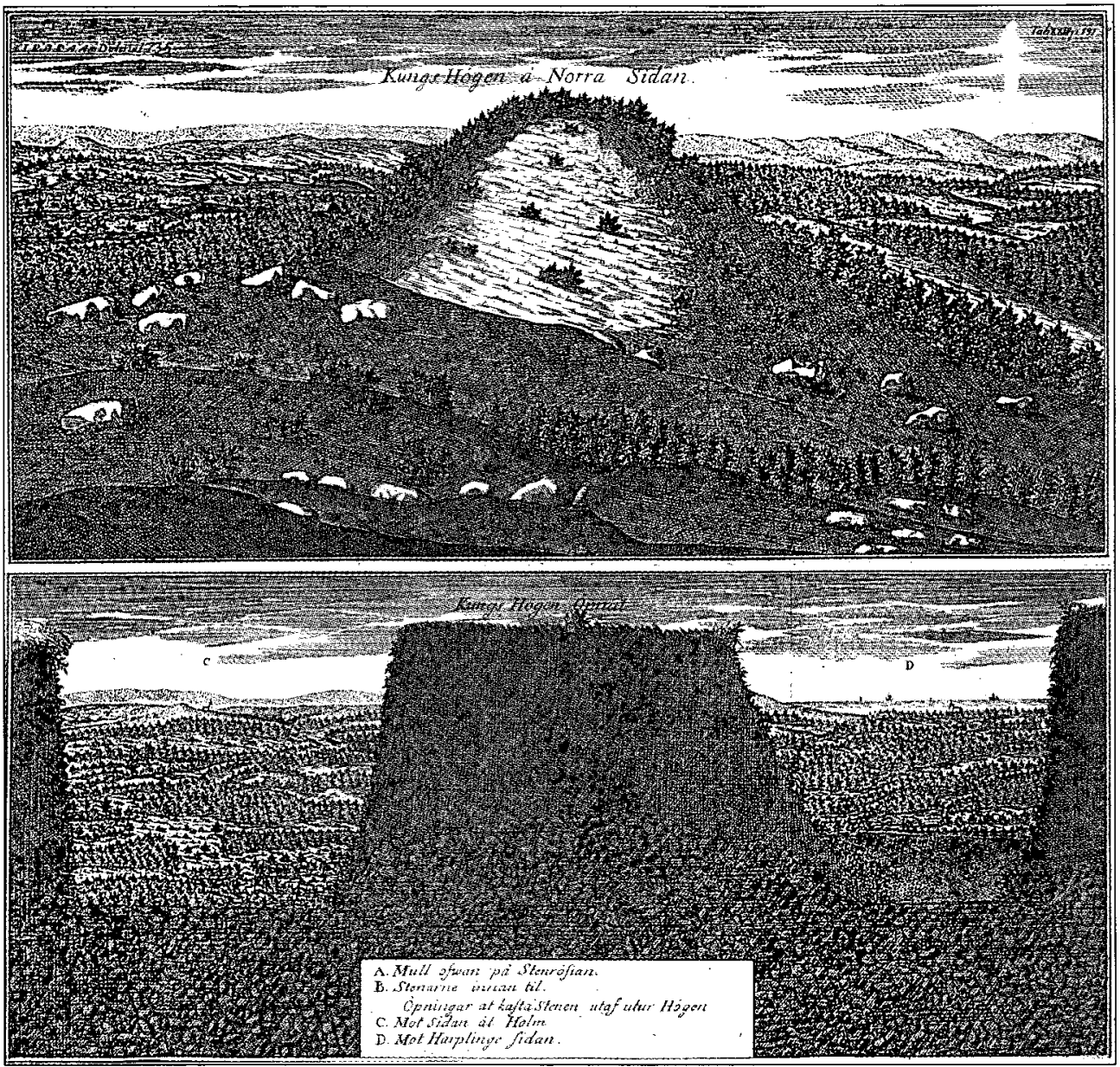

Fig. 9. A stratigraphical sequence of "Kungshögen" near Halmstad. Halland (Richardsson 1752-53, Table $X X I V)$.

cavator and each excavation was to some extent unique. A good example is, once again, Rudbeck, whose personal background, a Cartesian natural historian experienced in the art of dissection, undoubtedly affected his methodology. As Alain Schnapp has pointed out, Rudbeck was "one of the first to regard excavation as an act of anatomical dissection, an operation which consisted not just of removing objects from the soil, but of understanding the relationships of the remains to the layers which preserved them" (1996:200). However, Rudbeck was not alone, and to grasp the establishment of excavations we therefore have to move beyond the individual level and examine the supra-individual features that influenced the intellectual collective.

One obvious circumstance is the increasing specialisation of antiquarian work, which stimulated new kinds of interpretations and practices. In line with Ludwik Fleck (1997) and other constructivist theorists, I believe that new knowledge is 


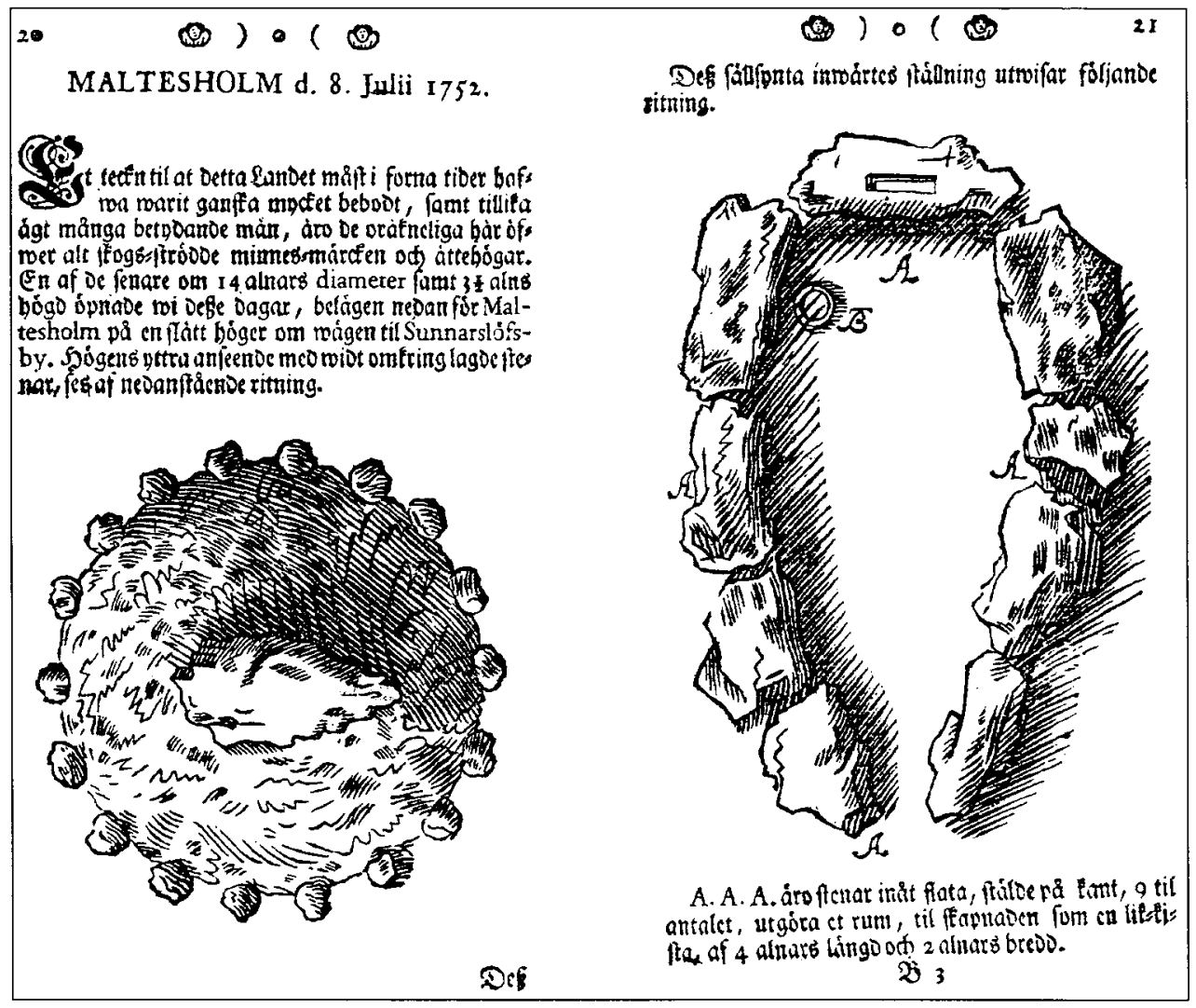

Fig. 10. A totally excavated barrow in Östra Sönnarslöv parish, Skåne, performed and illustrated by Carl Harleman in 1752. This rarely used strategy gave the excavator the opportunity to fully document inner constructions (Hårleman 1753:20-21).

socially constructed, though not in terms of some intellectual evolution. Nor was the field of antiquarianism autonomous or resistant to the rest of society and other spheres of knowledge. Antiquarianism was not the only discipline that focused on elements in the landscape and on features beneath the surface of the earth. The practice of excavating coincided with the birth of geology (see also Larsson 2000:92-93). Previously, the history of the earth had been primarily explained by the Bible, especially by the Book of Genesis. Changes and varieties on its surface were seen as the result of the Great Flood, which in turn implied a static view of its history. During the second half of the $17^{\text {th }}$ century, new factors, such as earthquakes, volcanic eruptions and floods, were added and made it clear that the earth had been modified also after the Great Flood (Frängsmyr 1969). To explain its mineralogical, geographical and topographical variations, more detailed studies were conducted, which in turn implied stratigraphical observations and the separate of natural formations from cultural exploitations. The co-establishment of geology and excavations was not a matter of chance but the consequence of a major shift of perception. 


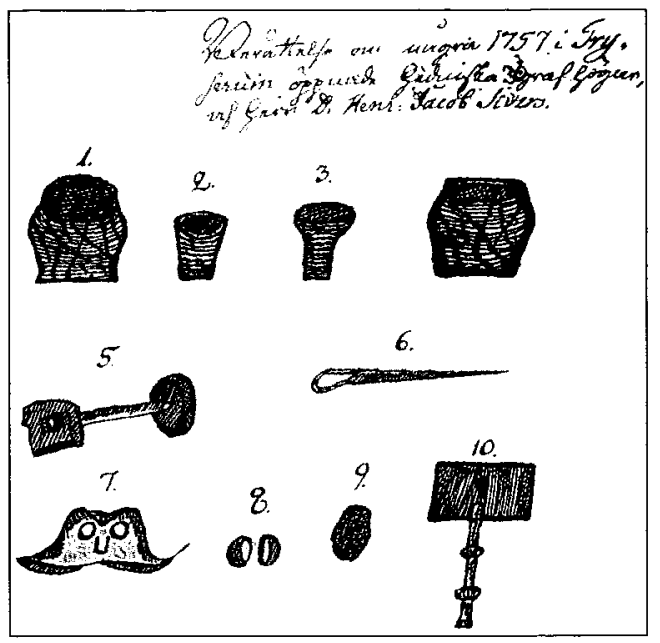

Fig. 11. Artefacts found in 1757 by Henrik Jacob Sivers during his excavation in Tryserum parish, Småland ( $F m$ 72, p 44).

Hence, to grasp the growth of excavation, we cannot be content to look for a single cause. Furthermore, we cannot be content to consider only the factors that stimulated its growth. It is equally important to look for the circumstances that at an earlier stage hampered antiquarians from investigating, different types of restraining effects.

\section{EPISTEMOLOGICAL AND ONTOLOGICAL CONDITIONS}

The rise of excavation as a practice coincided with a major epistemological and ontological shift which influenced the learned world as a whole. The $17^{\text {th }}$ century is commonly known as the age of scientific revolution and secularisation, which was influenced by Cartesian rationalism, scepticism and British empiricism. Antiquarian work was also affected by this intellectual mutation.

During the $17^{\text {th }}$ century, the image of the past was primarily based on written sources, most notably the newly discovered, Old Norse literature. This was due to a firm belief in older, authoritarian authors. Individual monuments and whole categories of antiquities gained their meanings from old texts and were therefore mainly used as illustrations and to confirm written information. However, the desire to combine written sources with more detailed, empirical observations can be detected during the later part of the century. As a result, antiquities as sources took on a somewhat more independent value. Even more important was the shift of focus concerning the monuments: Besides their exterior features, interest in their interiors was stimulated, such as how they were constructed and where the artefacts were found.

A good example of the influence of empiricism and source criticism, and consequently the new focus on

Fig. 12. An urn found in a barrow in Oja parish, Södermanland, in 1769. Illustrated by Samuel

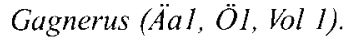

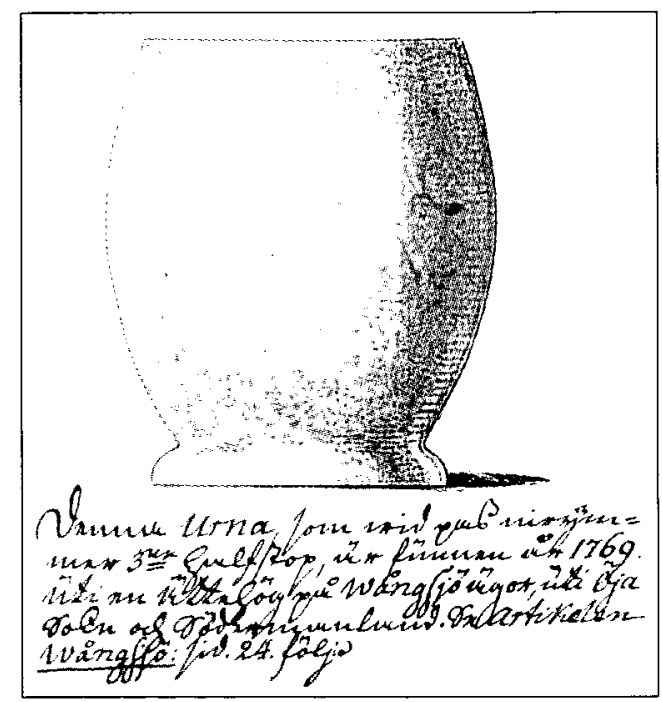


the interiors of monuments, is the excavation performed by Verelius. According to his own account, the reason for this enterprise was his doubt about the custom of cremation being prior to the custom of burying the dead uncremated in barrows. Verelius did not distrust the existence of this chronology, but he was convinced that both these customs had been practised side by side, at least for a time. In the barrow investigated, Verelius found both cremated and uncremated bones, which supported his theory. His excavation also proved that some information found in older books could, in fact, be wrong.

The sudden interest in excavating was not due only to an epistemological shift but also to an ontological one. During the Middle Ages and the Renaissance, the world was perceived as a living organism, literally Mother Earth. In line with this organic cosmology, the earth resembled a human being, a living and life-giving organism with organs and veins. This attitude had restraining effects on how the earth was treated: "The image of the earth as a living organism and nurturing mother had served as a cultural constraint restricting the actions of human beings. One does not readily slay a mother, dig into her entrails for gold or mutilate her body, although commercial mining would soon require that" (Merchant 1983:3). And she continues, "As long as the earth was considered to be alive and sensitive, it could be considered a breach of human ethical behaviour to carry out destructive acts against it" (ibid.). Mining, for example, was perceived as a very serious business and was therefore surrounded with rituals in order to appease the earth. Needless to say, this attitude also had restraining effects on excavating.

During the $17^{\text {th }}$ century, the organic view was gradually replaced by a mechanical and materialistic one. Earth was understood to be dead substance, acting according to universal laws appointed by God. As a consequence, the still-ongoing exploitation of the earth began. The declaration of this planet as dead is well illustrated by Rudbeck. In one of his pictures, he dissects the earth and lifts up its "flesh" - the ground - in order to prove that Sweden actually was the golden land that many classical authors had written about (Atlanticans planschband 1679, unpaged). As we all know, dissecting is preferably done on dead bodies!

\section{CHRISTIAN ETHIC}

In his description of the excavation, Verelius also gave an account of his strategy. Instead of digging a hole from the top to the centre of the grave, the barrow was excavated from its side (Verelius 1664:81 and in Jensen 1999:158). The reason he gave was twofold. Firstly, this strategy was considered less laborious. His second motive was that he did not want to disturb the spirits of the dead. The question is, of course, what influenced Verelius' strategy?

From a Christian perspective, any encroachments into graves were repudiated, especially if the intention was to desecrate the grave and/or to find treasure. Personally, I believe that this ethical standpoint had restraining effects on excavating for a long time. A good example is a royal prohibition from the first half of the $17^{\text {th }}$ century, which forbade searching for treasure in the barrows at Gamla 
Uppsala. The reason given was that it was not permissible to disturb the dead (Lindqvist 1936:275). Another example is Archbishop Olaus Magnus, who had a great interest in antiquities, which was expressed in his monumental work Historia om de nordiska folken (The History of the Nordic People), printed in 1555. However, it appears that he did not perform any excavations whatsoever, a circumstance which can be explained by the fact that he heavily condemned such desecration (2001:759-761).

The interest in preserving old graves was formalised legally by the law on antiquities passed in 1666. In the formulation of this law and in several documents connected with it, a central motive was repeatedly expressed; to make sure that the dead would not be disturbed (see Rann I 1960:XII-XVIII; Hadorph in Schück 1932:259). However, this restriction did not concern everyone. In a draft written in 1666, Hadorph put forward the suggestion that antiquarians should be excepted from the law and thereby have the authority to excavate as long as the monuments were restored afterwards (Hadorph in Schück 1932:259). Three years later, Hadorph himself asked the Chancellor of Sweden and the founder of the College of Antiquities, Magnus Gabriel de la Gardie, for permission to excavate Odens hög in Odensala parish, Uppland (Hadorph in Lindqvist 1936:18).

It should be noted, though, that, even if there was a law protecting ancient remains, there were seldom or ever any complaints about the hundreds or even thousands of monuments, mostly barrows, that were literally being obliterated from the face of the earth. As a matter of fact, it was not until the law protecting antiquities was passed in 1867 that excavations became legally regulated (SFS 1867). From then on, permission to investigate a monument had to be applied for.

\section{THE FEAR OF GHOSTS AND THE SEARCH FOR TREASURE}

The respect for the dead occupying old monuments was not solely due to the Christian ethical standpoint. According to an old and widespread notion, ancient graves were inhabited by evil ghosts, the dead, watching greedily over their grave goods (treasure). This notion had for a long time a twofold effect preventing antiquarians from excavating. Firstly, disturbing the occupant by digging or simply being too close to the grave could have serious consequences. There are quite a few examples from the $17^{\text {th }}$ century of actual illnesses, accidents and even deaths that were explained by such activities, and this had the effect of preserving the monuments. This idea was not restricted to popular belief but was also influential among the antiquarians (Jensen 2002:276).

Secondly, because prehistoric graves were commonly regarded as treasuries, antiquarians risked getting mixed up with yet another category of people if they explored them. Searching for treasure was for a long time perceived as a sinful and diabolical act. It was commonly believed that it was the Devil himself who had the supreme power over all buried treasure, which were in turn guarded by their evil owners. Hence, in order to secure these benefits, one had to get into contact with dark forces. In his Ethicae Christianae of 1617, Laurentius Paulinus 
Gothus gave a detailed account of the negative attitude towards treasure-hunting, which can be reduced to two major objections. For one thing, it was regarded as one of the Seven Deadly Sin (greed). Searching for and hiding treasure was therefore an often used theme already in medieval, Christian, didactic literature (Jensen 2002:168). The second objection was the methods used in the search for treasure. In order to spot the treasure and to cheat the owner out of it, incantations and magical artefacts, like special swords, divining-rods and church keys, were frequently used. These methods were classified as black magic and were therefore legally condemned.

A complement in the hunt for treasure was simply to enlist the help of someone who had the power to spot hidden and forgotten things. Several cases indicate that wise men and women were engaged in the search for treasure. In one example from 1551, a woman called "The Wise" announced that she had the gift of knowing in which mountains and barrows treasure were hidden (Rappr. I, 1551). In another example from the next century, a man called "The Master" was the one who actually led the search for a treasure in a so-called Steenkumle - some sort of cairn - in Gotland (Rann II, 1969:322).

If one find and withheld treasure from the state, one also risked being sentenced according to the medieval law on findings and lost properties, which was modified in 1684. And, in 1666, the law on the protection of ancient remains was passed, which implied that any encroachment and destruction, including the search for treasure, was from then on illegal. Hence, during the $17^{\text {th }}$ century, there were several parallel laws preventing the search for treasure. As a consequence, any exploration of ancient graves, including antiquarian investigations, was for a long time viewed with a certain suspicion. As late as 1757 , Sivers had to guarantee that he was not searching for treasure but for antiquities, before the suspicious locals let him conduct excavations (1758:330).

As we have seen, the apprehension that prehistoric monuments were inhabited by evil ghosts and contained valuable treasure had for a long time preventive effects on antiquarians conducting excavations. However, during the latter part of the $17^{\text {th }}$ and the early $18^{\text {th }}$ centuries, these notions were gradually transformed and declared to be fallacies and superstitions (Burke 1983:233-273; Jensen 2002:276-277, 361-363).

\section{EXCAVATION AS A NATURAL PRACTICE}

The final subject that I want to ventilate is why the popularity of excavations increased in the $18^{\text {th }}$ century. A fruitful way of grasping this is to compare and isolate possible changes in the motivations behind the excavations and also to look for differences in the way the monuments were perceived as objects of knowledge.

Beside the growth of empiricism and the search for gravegoods, the majority of the excavations conducted during the $17^{\text {th }}$ century were driven by two motivations. One of these was to explore graves associated with the ancient kings 
mentioned in the Old Norse literature (Jensen 2002:278). The focus on the older heroic kings was due to the ideology (Göticism) which at the time dominated the learned and the aristocratic part of society. Göticism implied a glorification of the ancient Swedish past and its royalties. The kings were perceived as key figures in the national history, an idea influenced by the predominant "theocratic" doctrine. According to this, the king was appointed by God himself and was therefore responsible only to him. A consequence of this fixation on kings was that most of the chronicles written were actually royal genealogies, listing one king after another. Furthermore, within Göticism, the ancient Swedish past was literally perceived as a golden age, a time of perfection, thanks to the Providence of God. The implication of this view was that the monuments in the landscape and the artefacts found within them were perceived as representing a state far better than the present. The excavations performed therefore resembled the early, religiously motivated explorations and the search for artefacts associated with a great ruler and/or a great period of history!

The second motive was to verify theories about past conditions mentioned in old texts. The reason why Verelius performed his excavation was, as was outlined above, to challenge the information given in some Old Norse texts. The purpose behind Hadorph's and Peringskiöld's investigation at Birka was to prove that Adam of Bremen, in his diocesan and episcopal chronicle from the $11^{\text {th }}$ century, had actually meant Björkö island in Lake Mälaren, and not one of the other alternatives that had been proposed (see Jensen 2002:278). And the reason why Hadorph wanted to excavate Odens hög in Odensala was to scrutinise the information given by Snorre. Owing to the fact that Rudbeck explored great many barrows without referring to any texts, he seems to have been an exception. The barrows at Gamla Uppsala were however, mentioned by Snorre, and the reason why Rudbeck in the 1670 s excavated the medieval church nearby was to prove that it was actually built on the ruins of the heathen temple mentioned by Adam of Bremen and also that it was identical with the temple of Apollo mentioned in classical texts (Rudbeck 1947:219, 417). Lastly, when Rudbeck dated barrows by measuring their layers, he used a chronology founded on yet another book, the Bible.

With the $18^{\text {th }}$ century, the interest in Göticism and theocracy declined. This was partly due to the end of Sweden as a great power, but also to the fact that God was gradually marginalised within the framework of history. Reinforced by the rationality of the Enlightenment, source criticism and empiricism became even more influential in the study of the past. Older beliefs in more or less supernatural, heroic kings and giants and other stories associated with ancient monuments were now classified as superstition and were therefore opposed.

This change of attitude affected and stimulated the art of excavating. Instead of focusing on specific monuments, such as those associated with ancient kings, the choice of objects became more unbiased. A new sort of antiquarian scepticism was fostered, which implied that the only way to know anything about the 
monuments was to perform excavations. The material found was more frequently analysed and ordered in terms of material, form and size.

Not everyone abandoned the basic ideas of Göticism. People with old-fashioned perspectives had intellectual struggles with the more critically oriented antiquarians and historians, controversies in which excavations became methodologically important. One controversial question was the existence of giants, which, as has been noted, stimulated von Linné to investigate an ancient grave. In 1763, Brocman was sent by the Archive of Antiquities to Fors parish, Hälsingland (Brocman 1766; Fe 23). His mission was to investigate a monument that was said to be the grave of a giant. Besides the monument in question, Brocman excavated several others, in order to prove his negative standpoint (Fig. 13).

Finally, the interest in excavating was also stimulated by an enlarged focus on the landscape. All its contents, its geography, its natural and economic elements and its cultural-historical features, were explored. Numerous descriptions of landscapes and parishes based on inventories were made, excursions which occasionally ended in excavations.

\section{SUMMARY}

The history of excavations in Sweden is complex but fascinating. In this article, I have argued that excavation as a practice was established during the second half of the $17^{\text {th }}$ century and became a natural practice in the next century. Several different factors have been highlighted. The growth of this method coincided with a major epistemological shift, which implied a growing influence of source criticism and empiricism. Previously, the main source of knowledge about past conditions had been older texts, above all, the Old Norse literature. Excavations

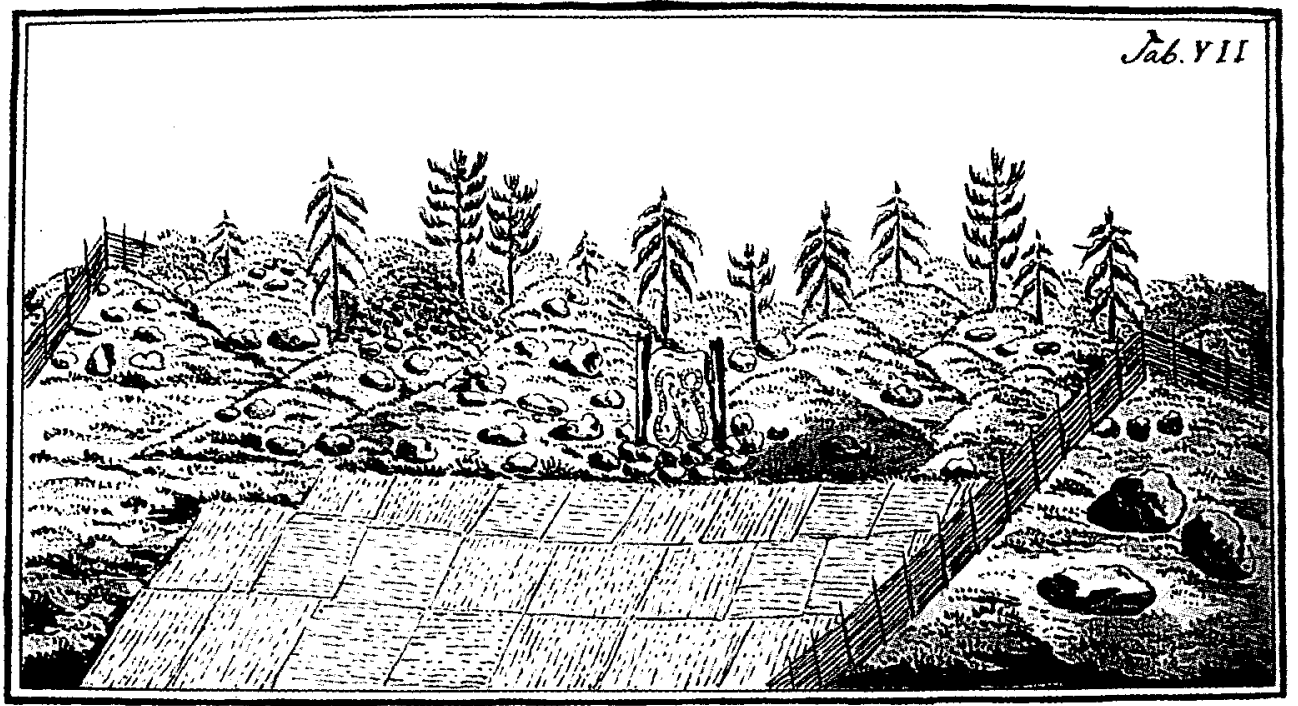

Fig. 13. A drawing of barrows and cairns situated near Gävle, Gästrikland, made by Olof Rehn. One of the cairns was investigated by Nils Reinhold Brocman in 1763 (Fe 23, Table VII). 
were introduced in order to complement and to test the information given in these texts. They were also stimulated by an increasing interest in collecting artefacts. Owing to the influential ideology called Göticism and the theocratic doctrine, both emphasising the greatness of kings, graves associated with ancient rulers were given priority.

I have also emphasised several factors that at an earlier stage prevented antiquarians from excavating. The earth was for a long time perceived as a living organism, which implied that any exploitation of it was perceived as a serious act. It was also believed that ancient graves were inhabited by evil ghosts, eagerly watching over their treasure. If one excavated these graves, one risked, on the one hand, being harmed by the ghost and, on the other, getting mixed up with a category of people who at that time were looked down on, i. e. treasure-hunters. A third restraining factor was the Christian ethical standpoint, from which any encroachment into graves was repudiated. When excavation as a practice was introduced, all these perspectives were altered. The earth was perceived as a dead substance created in order to be exploited; the idea of evil ghosts watching over their valuables was regarded as superstition, and the ethical standpoint against disturbing the dead was weakened. During the $18^{\text {th }}$ century, the influence of source criticism and empiricism increased, which in turn made excavation as a method even more important. This influence was also stimulated by intellectual squabbles and the test of hypothesis. Even more important was the enlarged influence in the landscape and its cultural-historical features.

As regarded on the characteristics of the excavations performed, the initiators were mostly men from the upper classes, whereas the men who actually performed the digging were peasants and soldiers. The type of monument excavated was, above all, barrows, which was due, on the one hand, to their popularity among the antiquarians and, on the other, because they were known for hiding grave goods. Owing to the focus on the artefacts, the methods used were similar to that used by the treasure-hunters - to dig a hole to the centre of the grave. By Olof Verelius and Olof Rudbeck, interest in construction details and stratigraphical layers was introduced. It emanated in a new excavation strategy, to dig shafts and to compile more detailed documentations. Rudbeck also developed the method of dating monuments by measuring their layers. Its popularity was, however, minimal and it was later criticised. To what extent the investigations were documented varied during the whole of the period. In time, the role of illustrations increased, especially concerning the artefacts found.

\section{ACKNOWLEDGEMENT}

This article is partly based on the results of my thesis (Jensen 2002) and is written within the framework of the project entitled "The History of Archaeological Practice in Sweden 1500-2000", financed by the Swedish Research Council. 


\section{REFERENCES}

\section{HANDWRITINGS}

Antikvariska topografiska arkivet (The Antiquarian Topographical Archive), Stockholm

Ämbetsarkivet 1 (Äal), Ö1, Vol 1. Berättelse av S. Gagnerus om "En liten Resa till Östergötland" 1770.

\section{Kungliga biblioteket (The Royal Library), Stockholm}

Fa 12. Bureus, Johannes, Collectanea Sumla kallad.

Fc $3 b$. Rhezelius, Johannes, Ornamenta Ölandica thet är Ölands grafstenar afrijtning och afsriffter i landz

kyrkiorne och kyrkiegårderne, ... 1634.

Fe 23. Brocman, Nils Reinhold, Berättelse om åtskilliga Ålderdoms Lemningar, i Anledning af ... Resa til

Helsingland.

Fm 53. Samlingsband. Smålands märkvärdigheter.

Fm 72. Strödda samlingar och anteckningar i antikvariska ämnen.

Ie 14:2. Ekeblad, Clas Julius, Journal 1761.

\section{Riksarkivet (The National Archives), Stockholm}

Riksarkivets pappersbrevsamling I (Rappr I), 1551 20/6, Fogden Kjell Nilssons dombrev 1551 20/6.

\section{PUBLISHED TEXTS}

Arwidsson, Greta. 1962. Lovö-bor med kontinentala förbindelser på 400-talet. In: P.G. Hamberg (Ed). Proxima Thule. Sverige och Europa under forntid och medeltid. Hyllningsskrift till H.M. Konungen den 11 november 1962. Utgiven av Svenska arkeologiska samfundet. Pp. 113-122.

Brendalsmo, Jan A \& Røthe, Gunnhilld. 1992. Haugbrot eller de levendes forhold til de døde - en komparativ analyse. META, 92:1-2. Pp. 84-119.

Brocman, Nils Reinhold. 1766. Berättelse, om en resa til Helsingland, förrättad af Herr Nils Reinhold Brocman, Assessor i Kgl. Antiquitets-Archivo, År 1763. Svenska magazinet. Pp. 551-562, 718-731.

Burke, Peter. 1983. Folklig kultur i Europa 1500-1800. Författarförlaget.

Dalin, Olof, von. 1767. Öfwer en händelse den 16 juli 1751, om aftonen. Herr Olof von Dalins Witterhetsarbeten i bunden och obunden skrift-ark. Andra bandet, Stockholm. P. 43.

Eriksson, Gunnar. 2002. Rudbeck 1630-1702. Liv, lärdom, dröm i barockens Sverige. Atlantis, Stockholm.

Fernow, Erik. 1977 [1773-79]. Beskrivning över Värmland. I-II. Ny utgåva av Arvid Ernvik. NWT:s Förlag, Karlstad.

Fleck, Ludwik. 1997 [1935]. Uppkomsten och utvecklingen av ett vetenskapligt faktum. Översättning Bengt Liliequist. Brutus Östlings Bokförlag Symposion, Stockholm.

Floderus Erik \& Gustawsson Karl Alfred. 1946. Fornforskning och minnesvård. In: A Schück et al (Eds). Ad patriam illustrandam. Hyllningsskrift till Sigurd Curman 30 april 1946. Almqvist \& Wiksells boktryckeri AB, Uppsala. Pp. 241-320.

Fredenheim, Carl Fredric. 1808. Tal, hållet vid inträdet i Kongl. Vitterhets, Historie och Antiquitets Academin d. 15 Dec. 1795. Kongl. Vitterhets, Historie och Antiquitets Academiens handlingar, Åttonde delen. Stockholm. Pp. 376-386.

Frängsmyr, Tore. 1969. Geologi och skapelsetro. Föreställningar om jordens historia från Hiärne till Bergman. Almqvist \& Wiksell, Stockholm.

Ganander, Christoffer. 1782. Kårt om de i Laihela Sockn i Österbotten befintliga sten- eller ättehögar. Tidningar utgifne af et sällskap i Abo. Den 13 julii 1782. N:o 28. Pp. 221-223.

Hadorph, Johan. 1687. Företaal. In: Gothlandz-laghen. På gammal göthiska/ med en historisk berättelse wid ändan/huruledes Gothland först är vpfunnit och besatt/så och under Swea rijke ifrån hedna werld altijd lydt och sin skatt giordt. Stockholm

Hildebrand, Bengt. 1937. C. J. Thomsen och hans lärda förbindelser $i$ Sverige. 1816-1837. Tiden till 1826. KVHAA:s handlingar, del 44:1.

Hilfeling, Carl Gustaf Gottfried. 1977. Hilfelings Skaanske tegninger. Dansk-Skaansk forening, Køpenhavn. Hårleman, Carl. 1753. Dag-bok ... 1752. Utg. Av H.H. von Liewen. Stockholm. 
Härnquist, Peter. 1779a-b. In: Götheborgs Allehanda, N:o 45 \& N:o 46.

Jensen, Ola W. 1999. Historiska forntider. En arkeologihistorisk studie över 1000-1600-talens idéer om forntid och antikviteter. Gotarc Serie C, Arkeologiska skrifter, No 29. Institutionen för arkeologi, Göteborgs universitet.

- 2002. Forntid i historien. En arkeologihistorisk studie av synen på forntiden och forntida lämningar, frän medeltiden till och med förupplysningen. Gotarc Serie B. Gothenburg Archaeological Theses No 19. Institutionen för arkeologi, Göteborgs universitet.

Klindt-Jensen. Ole. 1975. A History of Scandinavian Archaeology. Thames and Hudson, London.

Larsson, Stefan. 2000. Stadens dolda kulturskikt. Lundaarkeologins förutsättningar och förståelsehorisonter uttryckt genom praxis för källmaterialsproduktionen 1890-1990. Archaelogica Lundensia. Investigationes de antiqvitatibus urbis lundae, IX. Kulturhistoriska museet, Lund.

Laurentius Paulinus Gothus. 1617. Ethicae christiance pars prima, de retione bene vivendi. Thet är: Catechismi förse deel, om Gudhz lagh... Stockholm.

Lindqvist, Sune. 1936. Uppsala högar och Ottarshögen. KVHAA, 23. Wahlström \& Widstrand, Stockholm. Lindroth, Sten. 1997a. Svensk lärdomshistoria. Frihetstiden. Norstedts, Stockholm.

- 1997b. Svensk lärdomshistoria. Gustavianska tiden. Norstedts, Stockholm.

Linné, Carl, von. 1961. [1746]. Carl von Linnés Västgötaresa. Förrättad 1746. Stockholm.

- 1977 [1741]. Carl Linnœei öländska och gotländska resa förrättad 1741. Wahlström \& Widstrand, Stockholm.

Merchant, Carolyn. 1983. The Death of Nature. Women, Ecology and the Scientific Revolution. Harper, San Francisco.

Nordbladh, Jarl. 1997. Conducteuren C.G.G Hilfeling och hans samtid. In: A. Åkerlund et al. (Eds). Till Gunborg-Arkeologiska samtal. SAR Nr 33, Stockholms universitet. Pp. 527-537.

Olaus Magnus. 2001 [1555]. Historia om de nordiska folken. Gidlunds förlag, Hedemora.

Persson, Per \& Sjögren, Karl-Göran. 2001. Falbygdens gånggrifter: Del 1. Undersökningar 1985-1998. Gotarc Ser. C. Nr 34. Institutionen för arkeologi, Göteborgs universitet, Göteborg.

Rannsakningar efter antikviteter. 1960 \& 1969. Band I - II (Rann I-II). C I Ståhle (Ed). Text. KVHAA. Stockholm.

Rhyzelius, Andreas O. 1707. Sepultura sveo-gothorum. Upsalis.

Richardsson, Jacob. 1752-53. Hallandia antiqua et hodierna, thet är Hallands, et af Götha rikets landskaper, historiska beskrifning. Del 1-2.

Rudbeck, Olof. 1679. Atlanticans planschband.

- 1937. Atlantica I. Olof Rudbeck Atland eller Manheim, första delen. Lychnos bibliotek, 2:1. Uppsala och Stockholm.

- 1947. Atlantica III. Olof Rudbeck Atland eller Manheim, tredje delen. Lychnos bibliotek, 2:3. Uppsala och Stockholm.

Schantz, von Carl Ludvig. 1725. Nobilissimi Viri C. L. Von Schantz, Coll Antiq. Assessoris, narratio accurata \& succincta de perfossione tumuli sepulcralis in Upplandia, territorio Semminghundrensi, paræcia Orkesta \& prædio Waxtuna. In: Acta literaria Svecice, Upsaliæ \& Stockholmiæ. Pp 34-36.

Schnapp, Alain. 1996 [1993]. The Discovery of the Past. The Origins of Archaeology. British Museum Press, London.

Schück, Henrik. 1932. Kgl. Vitterhets historie och antikvitets akademien. Dess förhistoria och historia. I. Antikvitetsstudiets början. Stockholm.

- 1935. Kgl. Vitterhets historie och antikvitets akademien. Dess förhistoria och historia. IV. Antikvitetsarkivet I. Stockholm.

- 1943. Kgl.Vitterhets historie och antikvitets akademien. Dess forrhistoria och historia. V. Antikvitetsarkivet II. Stockholm.

Swensk författnings-samling för 1867 (SFS 1867), No 71. Kongl. Maj:ts nådiga Förordning angående forntida minnesmärkens fredande och bewarande.

Schröder, Johan Henrik. 1817. Tillägg wid anmärkningar om ättehögar. Iduna 7. Pp. 211-212. 
Sivers, Henric Jacob. 1758. Berättelse om några nyligen i Tryserums Sokn, Tiust Härad och Calmare Län, öpnade Hedniska Grafhögar och the theruti fundna Saker, ... Det Swenska Biblioteket. Andra Delen, 1758. Pp. 328-348.

Stjerna, Knut. 1906. Tvenne fyndplatser från 1752. Fornvännen Årg 1. P 7.

Stobaeus, Andreas. 1708. De antiqua urbe Lund.

Ström, Severin Jacobsson. 1973 [1758]. Beskrifning om Wädtle härad med uptekning af de märkwärdigheter; som deruti sig tildragit hafva, både i det werldsliga regementet och kyrko wäsendet ifrån de äldsta tider tilbaka. Utgiven av Skallsjö Hembygds- och Fornminnesförening.

Sturluson, Snorre. 1994. Nordiska kungasagor 1. Från Ynglingasagan till Olav Trygvassons saga. Fabel bokförlag, Stockholm.

Trigger, Bruce. 1989. A History of Archaeological Thought. Cambridge University Press, Cambridge.

Trotzig, Gustaf. 1987. Forntiden förr och nu - och i framtiden. In: Forntid och framtid. En vänbok till Roland Pålsson. Riksantikvarieämbetet och Statens historiska museer, Stockholm. Pp. 56-70.

Uppländska häradsrättsdomböcker från 1500-talet (UHRD). 1942. Supplement innehållande anmärkningar, förklaringar och sakregister utgivet genom Nils Edling. Uppländska domböcker utgivna av Kungl. Humanistiska vetenskapssamfundet i Uppsala. VI. Uppsala.

Wessman, Nils. 1758. Berättelse om min resa genom Blekinge och Skåne. Den swenska Mercurius, tredje årgångens tredie del. Pp. 1310-1317.

Wideen, Harald. 1976. En gravundersökning i Uddevallatrakten på 1600-talet. Särtryck ur Bohusläns Hembygdsförund årskrift 1976.

Verelius, Olof. 1664. Gothrici et Rolfi Westrogothia Regum Historia. Upsaliæ.

Vollin, Jonas. 1933. På Kinnekulle sommaren 1750. Pp. 73-91. In: Med göter genom göternas rike. Sockenbeskrivningar valda, utgivna och kommenterade av Harald Schiller. Författarens Förlag, Malmö.

Åkerman, Israel. 1774. Berättelse om ett urminnes-märke, hittat på Gothland och Hemse kyrkogård år 1767. Stockholm. 